\title{
Gómez Farías y Santa Anna: correspondencia en tiempos de crisis, 1847
}

\author{
Laura Solares Robles \\ INSTITUTO MORA
}

Siete cartas de Gómez Farías que dan razón de la situación económica del país en el periodo inmediatamente anterior a la invasión estadunidense.

$\mathrm{E}$

1 déficit presupuestal del Estado mexicano lleva en sí mismo una larga historia; casi desde su nacimiento como nación independiente, el país tuvo que enfrentarse a graves problemas económicos.

El gobierno de Guadalupe Victoria no se vio apremiado al principio por necesidades económicas pero, debido a las gestiones del gobierno de Agustín de Iturbide para obtener algunos préstamos, para 1827 el régimen ya registraba un déficit sustancial. En aquel entonces se intentaba subsanar esta situación recurriendo a los grupos e instituciones que tenían el capital suficiente para proporcionar préstamos al gobierno: los ricos propietarios de tierras, los usureros y la
Iglesia. Sin embargo, eso no era la solución o, por lo menos, no la mejor.

La tremenda inestabilidad política que siguió al gobiemo de Victoria no permitió dar solvencia financiera al Estado. Los impuestos que éste recaudaba de los mexicanos ricos no eran fácilmente cobrablesy las alcabalas recaían duramente sobrelos pobres; innumerables informes de Hacienda demuestran la poca disposición de los mexicanos ricos para cubrir los gastos del gobierno.

En ese afán por obtener recursos, Valentín Gómez Farías inició negociaciones en 1833 con un grupo de especuladores, entre los que se contaban Antonio de Garay y Anselmo Zurutuzu. El primero de ellos fue incluido en el gabinete como 
ministro de Hacienda; así se inició una relación entre usureros y gobierno que parecía benéfica, pues los agiotistas cubrían inmediatamente los préstamos solicitados.

Sin embargo, los préstamos no cubrieron por completo los desbalances presupuestales de los gobiernos siguientes; en consecuencia, se recurrió continuamente a las otras opciones ya conocidas como el estanco del tabaco, las alcabalas, los impuestos internos y los préstamos de la Iglesia entre otros.

Valentín Gómez Farías desempeñó en dos ocasiones el cargo de presidente por ausencia de Santa Anna, quien había sido "el elegido". Las dos veces se vio colocado en situaciones por demás preocupantes: un erario exhausto, las arcas del gobierno vacías y el compromiso de sacar adelante el nuevo gobierno apenas instalado.

En 1833 Valentín Gómez Farías y José María Luis Mora intentaron poner en práctica una serie de reformas que contemplaban modificar las relaciones con la Iglesia y construir un Estado fuerte, sin competencia que debilitara su poder; se pondrían en circulación muchos capitales y propiedades, que hasta entonces se encontraban en manos muertas, con la intención de propiciar el desarrollo de los propietarios y de los ciudadanos, lo que redundaría en producción y progreso.

Al suprimir el artículo constitucional sobre intolerancia religiosa, la reforma pretendía lograr, entre otras cosas, la libertad de cultos y abrir la posibilidad de que numerosos extranjeros vinieran a colonizar las tierras deshabitadas; la educación pasaría a ser obligación del Estado impidiendo, hipotéticamente, la manipulación ideológica de la población; los partidos políticos dejarían de aliarse con el clero o el ejército en busca de apoyo para llegaral poder, reduciendo la inestabilidad.

Muchas eran las ventajas que se obtendrían con las reformas, pero el proyecto no pudo llevarse a efecto. Sin embargo, las imágenes de Gómez Farías y de Mora serían, a partir de entonces, la de aquellos hombres que atentaron contra la Iglesia. De ahí que más adelante, en 1846, cuando de nuevo Gómez Farías asume el poder, se vea en él la figura del anticlerical que atacaba el poder y los bienes de la Iglesia.

Si bien ésta había colaborado casi siempre con el gobierno, los reformistas no consideraban suficiente el papel que había jugado en la resolución de los problemas financieros del Estado. En consecuencia, la tentativa de Mora y Farías iba en el sentido de utilizar el producto de la venta de los bienes que la Iglesia tenía sin producir.

La voz popular atacó a Gómez Farías por ser el ejecutor de una propuesta que no era la primera ni la única; acaso esa voz desconocía que Lorenzo de Zavala ideó que el gobierno tomara posesión inmediata de los bienes de la Iglesia y que los vendiera rápidamente en subasta pública, destinandolo recaudado para liquidar adeudos. Fue Gómez Farías el primero que se negó a apoyar dicho proyecto al señalar que los únicos beneficiados serían los especuladores que, con la adquisición de dichos bienes, consolidarían aún más su posición de poder en el Estado.

Finalmente, la expropiación de los bienes de la Iglesia no se verificó por múltiples razones; una de ellas fue la falta de un grupo que tuviera la solvencia económica necesaria para comprar los bienes y proporcionar dinero suficiente al gobierno.

A partir del fracaso de las medidas de Gómez Farías, la Iglesia se alió aún más 
con el grupo centralista y, por ende, con el ejército. A partir de entonces, los gastos de la tesorería aumentaron todavía más y con ello el déficit presupuestal.

Aun cuando el centralismo funcionó bien con respecto a "salvar" a la Iglesia de una rápida pérdida de sus bienes terrenales, contribuyó a complicar otros problemas que, años más tarde, serían decisivos para el Estado mexicano: tal fue el caso de la dificultad enorme para "cuidar" su vasto territorio. De ahí que la separación de Texas diera pie a un nuevo deseo por parte de Estados Unidos de América de apoderarse de más territorio mexicano.

Después del de Gómez Farías se dieron numerosos intentos por recolectar fondos para el gobierno. El mismo Santa Anna se vio obligado a atacar duramente a la Iglesia en los años de 1842-43, periodo en el que expidió numerosos decretos anticlericales, entre los que destaca la venta forzosa de los bienes del Fondo Piadoso de las Californias y así establecer el precedente para que, en el futuro, los bienes de la Iglesia fueran vendidos a los prestamistas.

Ni la estructura federalista ni la centralista lograron en 20 años sacar adelante al país de sus embrollos económicos, por eso, desde el momento en que EUA irrumpió en territorio mexicano con la clara intención de apoderarse de una vasta extensión, el gobierno mexicano intentó una vez más obtener recursos, sólo que esta vez con un afán distinto: proporcionar ayuda al ejército que tendría que enfrentarse al invasor estadunidense.

La situación hacendaria no era muy diferente en 1845 a la que se había vivido en décadas anteriores: de nuevo se recurrió a las opciones ya conocidas, el estanco del tabaco y la Iglesia.

La amenaza de guerra materializada en mayo de 1846, puso al gobierno de Mariano Paredes en un grave aprieto: obtener los suficientes recursos para detener al enemigo. La situación era desesperada, el bloqueo a los puertos impedía la recaudación de las aduanas; la Iglesia se resistía cada vez más a proporcionar las contribuciones que se le solicitaban y, para colmo, nuevos pronunciamientos internos acabaron con los pocos recursos gubernamentales.

Los 700000 duros que el gobierno de Paredes había dejado en las arcas nacionales fueron consumidos en la sublevación promovida por Mariano Salas para deponerlo y en los festejos a Santa Anna que de nuevollegaba al poder para salvar al país. Las culpas del caudillo habían sido olvidadas y perdonadas y se preparaba el terreno para las elecciones que llevarían a la pareja Santa Anna-Gómez Farías al gobierno como ya lo habían hecho en 1833-34.

De nuevo Gómez Farías quedó al frente del ejecutivo cuando Santa Anna marchó a defender el territorio amenazado. Esta vez Gómez Farías se enfrentó a un complejo panorama económico, por cierto nada novedoso: escasos recursos hacendarios y muchos requerimientos financieros, entre los que destacaba la manutención del ejército, instalado en San Luis Potosí, al mando de Santa Anna.

Desgraciadamente para Gómez Farías y para el país, las intenciones del gobierno estadunidense, en cuanto a la penetración que hacía en territorio mexicano iba más allá de lo evidente y, desafortunadamente, grupos poderosos, como los prestamistas, no estaban dispuestos a comprometer sus intereses personales en función de la salvación del país. Como atinadamente señala Barbara Tenenbaum: "ni siquiera la amenaza del aniquilamiento de la nación los llevó a 


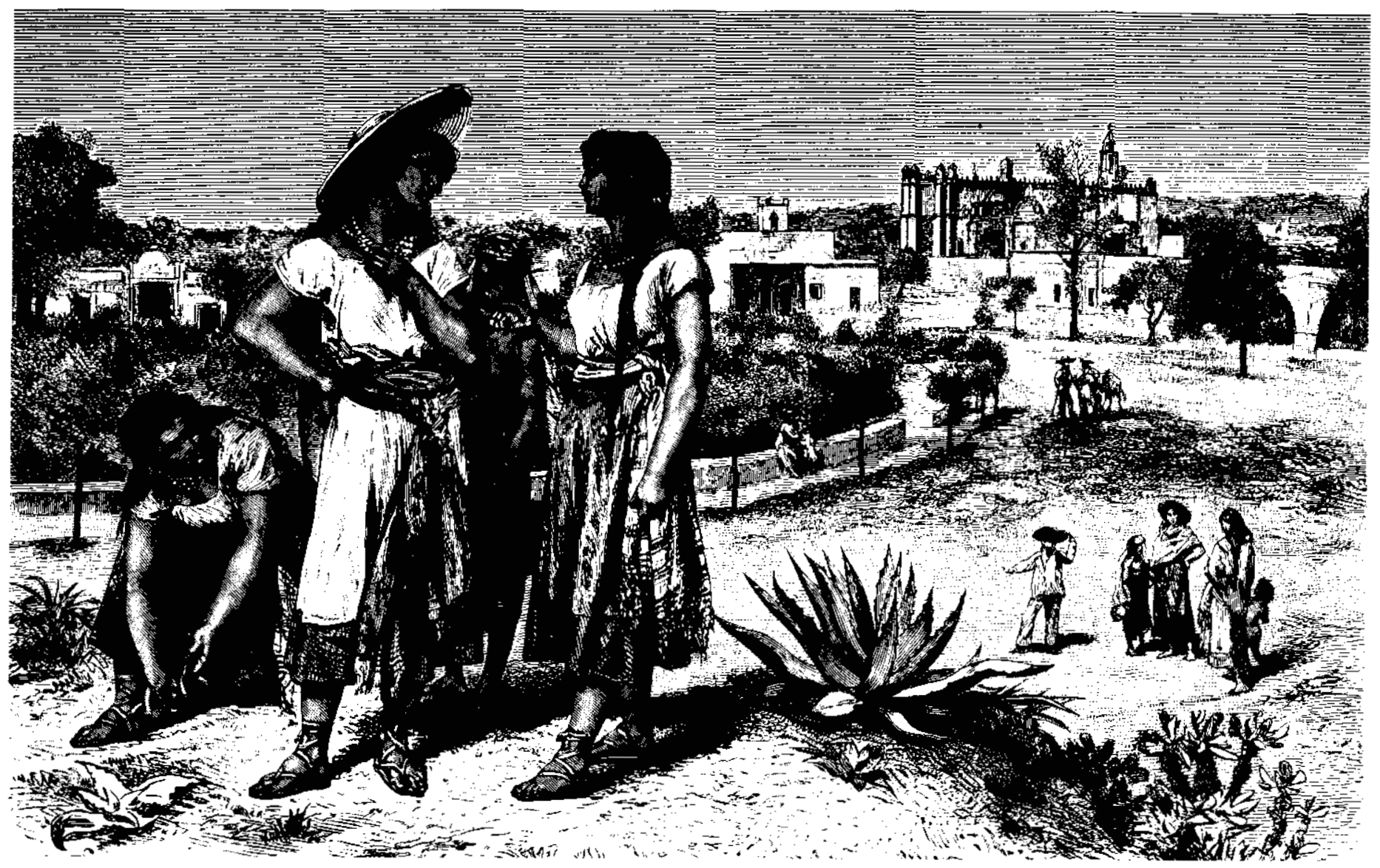

hacer a un lado sus diferencias y unirse tras un solo dirigente". ${ }^{1}$ A causa de esto, las gestiones al respecto no dieron frutos.

Sería injusto señalar como únicos responsables de esta escasez de numerario a los prestamistas y comoúnica causa de la derrota a aquélla. Muchos otros factores contribuyeron al fracaso militar: el abandono de Santa Anna de las plazas que debía defender, la apatía de los estados para unirse en un frente común, la reserva de la Iglesia para proporcionar los recursos de que era capaz, etcétera.

Aun cuando desde octubre de $1846 \mathrm{el}$ ministro de Hacienda, Antonio Haro y Tamariz, concibió un plan para desamortizar los bienes del clero, fue nuevamente Gómez Farías quien se vería en la nada grata tarea de decretar un préstamo forzoso a la Iglesia y así poder enviar

${ }^{1}$ Barbara A. Tenembaum, México en la época de los agiotistas, 1821-1857, Fondo de Cultura Económica, México, 1985, p. 90. dinero a Santa Anna para combatir a los estadunidenses.

Gómez Farías de nuevo sería tachado de anticlerical, de inepto y de radical, y echado de la silla presidencial.

Las cartas que se presentan a continuación forman parte de un enorme y valioso archivo (más de 4500) que se encuentra en Austin, Texas, en la Colección Latinoamericana de la Biblioteca Nettie Lee Benson; son una pequeñisima muestra del valioso acervo que constituye el archivo quelleva su nombre y dan cuenta de los afanes de dos hombres, Antonio López de Santa Anna y Valentín Gómez Farías, por lograr cada uno a su manera el desarrollo del país. En ellas se presentan como cualquier hombre colocado en circunstancias adversas: comprobamos su pasión, su enojo, su desesperación, su patriotismo y su confianza. Acaso su salida a la luz, aclare y contribuya a la comprensión de la situación en que estos dos hombres se vieron sumergidos por su propia decisión. 
1

\title{
APROBACIÓN DEL DECRETO*
}

\author{
Señor general \\ don Antonio López de Santa Anna, \\ [enero 1 de 1847].
}

Por fin ha quedado definitivamente aprobado el decreto para la ocupación de los bienes del clero hasta el valor de 45000000 de pesos. Fuerte y tenaz ha sido la resistencia, muy acalorados los debates. Fue preciso que la cámara se declarase en sesión continua y permanente que duró todo el día de ayer y toda la noche hasta esta mañana a las 8 o 9 que concluyó. Por el Ministerio de la Guerra le mandé a usted copia del mencionado decreto y muy pronto se le mandarán a usted los recursos de que tanto necesita. Me ocupó en forma el reglamento y sin duda que producirá los mejores resultados. Asimismo amigo mío, grandes han sido los [obstáculos] que hemos tenido que vencer, pues también, yo lo espero, grandes y benéficos serán los resultados.

V.G.F.

2

\section{SANTA ANNA IMPLORA RECURSOS A VALENTÍN GÓMEZ FARÍAS Y NARRA SU DESESPERACIÓN**}

Excelentísimo señor don

Valentín Gómez Farías, San Luis Potosí, enero 4 de 1847.

Mi estimado amigo y compañero:

Hoy despacho un extraordinario para ésa con el especial objeto de pedir recursos al gobierno. Estamos a 4 y no sólo no se ha recibido dinero para el presente mes sino que faltan aún más de 200000 pesos para cubrir el presupuesto anterior. Mi situación es la más crítica puesto que tengo fuerzas de

*Archivo de don Valentín Gómez Farías de la Colección Latinoamericana de la Universidad de Texas en Austin (en adelante TxU, G.F.), 2227. Las fechas que aparecen en corchetes son tentativas y fueron tomadas del catálogo del Archivo de Valentín Gómez Farias elaborado por Pablo Max Ynsfran.

*TxU, G.F., 2262. 
consideración avanzadas y cerca del enemigo que no cuentan con otros recursos que los que yoles mande. Yo nada puedo enviarles porque nada recibo y de consiguiente preveo que si no se acude pronto al remedio van a realizarse mis tristes pronósticos. Sé que ya en el ejército se murmura con respecto al abandono en que el gobierno lo tiene y no sé que determinación podré tomar en el caso de que seriamente me pidan lo que yo debía haberles dado ¿Qué castigo podré yo imponer al soldado que se deserte para buscar por otro lado su subsistencia cuando aquí se le niega? ¿Podré reconvenir al oficial que contraiga compro-

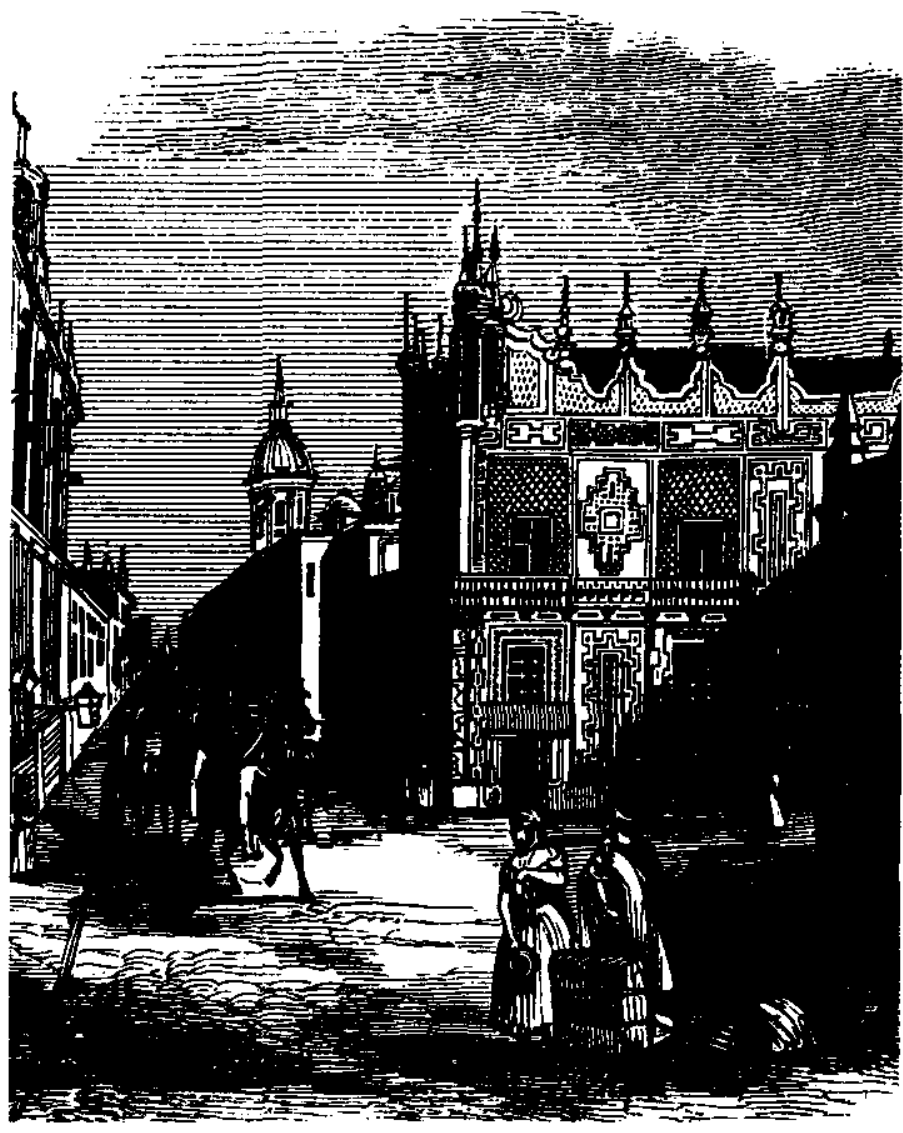
misos y no los cumpla porque cuenta para ello con lo que se le debe y no se le paga? Haga usted por Dios, mi buen amigo, un esfuerzo y vea de mandarme recursos a vuelta del extraordinario. No dudo del patriotismo de usted que así lo efectuará a fin de evitar las funestas consecuencias que he previsto. Mi firma esta ya comprometida por una cantidad respetable y por éste y por la paralización de este comercio me es imposible sacar más fruto de ello. Mi responsabilidad como general en jefe es muy grande: la nación tiene en mí puestos sus ojos y no puedo corresponder a sus deseos y esperanzas porque la escasez de numerario me tiene atados los brazos. Y si inmediatamente no recibo recursos me veré en la precisión de dar un manifiesto que me justifique y haga ver que no puedo ser responsable de los resultados de la miseria puesto que repetidísimas veces he hecho los debidos reclamos sin que se me haya atendido como se debía. Así pues repito que vengan fondos al momento.

Una manifestación mía no sólo desprestigiaría al gobierno sino que pondría al enemigo al tanto de nuestra situación y él se aprovecharía de las circunstancias. Por esta razón no me explico aún públicamente esperando que usted hará el mayor esfuerzo porque no llegue semejante caso.

Consérvese usted con la mejor salud y mande cuanto guste a su afectísimo amigo, compañero y seguro servidor que besa su mano.

A. L. Santa Anna (rúbrica) 


\title{
3
}

\section{OPINIÓN DE GÓMEZ FARÍAS SOBRE LA}

\section{AMENAZA DE REVOLUCIÓN Y GUERRA*}

\author{
Excelentísimo señor general \\ don Antonio López de Santa Anna, \\ México, enero 4 de 1847. \\ Reservada
}

Mi muy estimado amigo: he demorado la contestación a las dos cartas de una misma fecha, no sólo con el objeto de indagar los antecedentes que puede tener la revolución que usted me anuncia, y que según otra carta que he visto de usted mismo, se la figura tan segura, que temía hubiera estallado en esta capital, sino también con el de esperar el resultado de una junta que celebró ayer el ministro de Hacienda para proporcionarse algunos recursos. El partido decembrista demasiado tenaz en sus pretensiones aspira y aspirará siempre a apoderarse del mando, pero como no tiene valor suficiente para conquistar el poder con la fuerza, emplea las intrigas y los engaños que son sus armas, no se descuide usted amigo mío y sea presa de sus artificios. En prueba de los medios infames de que se sirven los decembristas voy a referir a usted un hecho reciente que he oído contar al amigo Perdigón. Rodríguez Puebla según me ha dicho, le habló fingiéndose interesado por la elección de usted mostrando sentimientos por que los federalistas no querían votarlo siendo evidente que éstos trabajaban incesantemente y activa [ilegiblel en favor de usted y los moderados en contra, como está acreditado por la votación que habrá usted leído en los papeles públicos. Los hombres que lanzaron a usted de su patria ven con sumo disgusto su regreso y si a mí me persiguen, la causa principal es por que concurrí eficazmente a que usted volviera, y por que fiel a mis compromisos trabajé por que fuera usted electo presidente; saben ellos que llegué a decir a un íntimo amigo mío que rehusaba votar a usted y era único diputado por su estado, que si no le daba su sufragio, no quería que me lo diera a mí; y que si no resultaba usted nombrado presidente yo renuciaría en el acto a la vicepresidencia. Refiero estas cosas $\sin$ más objeto, que el que usted conozca su situación, sabiendo lo que ha pasado y para que se procure de muchos que fingiéndose amigos, pueden sorprenderle. Veo que efectivamente se trata de una revolución, y que ambos somos objeto de ella, pero también veo que no contando nuestros enemigos con 


\section{SECUENCIA}

todos los elementos necesarios para hacerlo, quieren dividirnos, procuran ponernos en confusión, inspirar por todas partes [ilegible] y tenernos en continua alarma. De todo se aprovechan para lograr sus fines. Varias veces dicen que la soberanía de los estados no es respetada por usted; otros que la guerra contra Estados Unidos es una ficción, que hay compromisos para no hacerla, que se proclama sólo para pedir dinero; que nuestras escaseces provienen de que no se emplean en el ramo de Hacienda hombres que no manejen con pureza las cantidades públicas; de que [...] consulta para dar los destinos la probidad y la inteligencia; sino las afecciones privadas [ilegible] que la dirección de la hacienda se confía a manos no sólo inexpertas, sino disipadoras [ilegible].

4

SANTA ANNA AMENAZA A VALENTÍN GÓMEZ FARÍAS*

Excelentísimo señor don

Valentín Gómez Farías,

San Luis Potosí, enero 7 de 1847.

Mi muy estimado amigo y compañero:

Observo que los chismes y cuentos de esa malhadada capital, han absorbido de tal modo la atención de usted, y de su ministerio, que enteramente se han olvidado de que existe aquí un ejército de más de 20000 hombres al frente del enemigo, que debe comer y cumplir también con las obligaciones de su instituto; pues hace quince días que se ha instalado el gobierno de usted y no ha mandado ni un solo peso a esta comisaría, de manera que se me ha reducido a la situación más desesperada y comprometida de mi vida; porque naturalmente todos ocurren a mí por el haber que les pertenece, y todos se quejan y lamentan, a su modo, de la situación.

Sin duda que usted no ha reflexionado por esas atenciones, la situación que guarda actualmente el país, ni lo que son nuestros hombres, que saben sacar partido de todas las circunstancias; porque si usted pensara bien sobre ésta, no vería con tan fría indiferencia, que a este ejército se le hostiliza matándolo de hambre con más rigor que pudieran hacerlo los yanquis. Se da

•TxU, G.G., 2285. 
lugar con esta conducta a que los militares lleguen a pensar que hay un designio por parte de usted para reducirlos a tan aflictiva situación, y juzgue usted a la mala trascendencia que tendrá esta idea si se propaga, o la sugieren de esa capital los enemigos del gobierno y de la paz pública.

Como el asunto es tan grave, ya no debo andar con rodeos para presentarle la verdad pura y desnuda. Hago pues saber a usted, que si a vuelta de este extraordinario no vienen libramientos que nos saquen de la horrorosa miseria que nos cerca, voy a publicar un manifiesto a la nación para patentizarle la situación a que me veo reducido, y por qué no puedo mover ni un soldado sobre el enemigo, cuando éste se nos va acercando cada día. Publicaré lo que al gobierno del general Salas dije, y lo que he dicho al de usted para que cada cual cargue con la parte que le corresponda en el juicio de nuestros conciudadanos. No tengo otro medio de salvar mi reputación, que estimo demasiado, y de eximirme de la grande responsabilidad que pesa sobre mí, por haber querido cubrir nuestra situación impulsada de un noble sentimiento en honor del país.

Si ni aun el manifiesto fuere suficiente a remediar la situación pediré a usted que nombre un general que se encargue del ejército para retirarme a mi casa, y no verme envuelto en un porvenir desastroso, como es consiguiente si a este ejército se le tiene por más tiempo en el abandono y en el olvido.

No se me oculta la situación en que usted ha encontrado las arcas del tesoro público, las pocas facultades que usted tiene y otros motivos que le impiden proporcionar de pronto cuanto es necesario; pero mi deber es manifestar a la nación la situación que guarda el ejército que se ha puesto a mis órdenes para defender sus más caros intereses, y ya no me es posible guardar silenciosobre asunto tan grave y trascendental. El gobierno del general Salas debió haber dejado provista esta tesorería antes de retirarse del puesto, porque tuvo facultades suficientes para sacar recursos, y sobre él pesará la responsabilidad a que haya lugar. Esto no obstante los enemigos de usted han de pretender que su gobierno sea el único responsable.

No hay lugar para más: me repito de usted como siempre afectísimo amigo y seguro servidor que besa su mano.

A. L. de Santa Anna 


\title{
5 RESPUESTA DE VALENTÍN GÓMEZ FARÍAS A SANTA ANNA EN DONDE LE MANIFIESTA SU ENOJO*
}

\author{
A Antonio López de Santa Anna \\ [Enero 7 de 1847].
}

Acabo de recibir por extraordinario una carta de usted cuyas expresiones me ofenden demasiado. Yo, amigo mío, no me ocupo de chismes, ni mi genio es [darles] cabida; acaso usted está más expuesto que yo a ser sorprendido, por ello como puede inferirse de varias de sus cartas, en que supone al estallar revoluciones por diferentes puntos, y a esta capital, presa ya de un trastorno peligroso, siendo así que desde que yo tomé posesión del gobierno no se ha alterado la tranquilidad pública, y que difícilmente se atreven a turbarla los enemigos de la independencia y de la integridad del territorio nacional. Me dice usted en su carta que se había pasado decir que viene sin firmar.

En una carta de usted sin firma, que he recibido anoche por extraordinario veo algunas expresiones que me ofenden. Dice usted en ella que me ocupo de chismes y que la falta de recursos para el ejército podrá atribuirse a que le tenga desafecto; lo primero, señor general, es tan contrario a mi genio que veo con sentimiento que usted es el que les da acogida, pues ha llegado a suponer que están al estallar revoluciones por diferentes puntos en donde no se deben temer, si no es que se provoquen con hechos que aumentan la desconfianza y los recelos, que a pesar de mis esfuerzos no se han podido del todo deșvanecer. Tanto han sorprendido a usted algunos falsos amigos, a quienes tiene la desgracia de dar oído, que ha llegado a suponer que aquí estábamos positivamente en revolución, siendo así que no se ha alterado en lo más mínimo la tranquilidad pública y sé que hay personas que quisieran un cambio a toda costa, pero como las conozco y las observo, si llegan a los hechos, los escarmentaré pronto. Si usted conociera a los hombres y reflexionara más sobre su prisión, no correspondiera mal a mi lealtad, a mis servicios, y. a la noble franqueza y sinceridad con que me he conducido hasta hoy. Esas especies que parece se quieren empezar a difundir, de que por no proveer al ejército de recursos, son injustas y acaso maliciosas. Me afano como el que más por asistirlo con todo lo necesario, pero cualquiera conocerá que es imposible lograr en quince días crear fondos por los medios ordinarios y 
legales. He recibido un erario enteramente exhausto; no cuento con los ingresos de aduanas marítimas, me he encontrado gravada la hacienda nacional con enormes sumas; he visto con dolor que algunos de los que llama usted sus amigos han concurrido a arruinarla, y que a usted se inculpa porque se le atribuye en todo o en parte su colocación. En estas circunstancias aunque muy aflictivas no he desmayado, a tan grandes dificultades he opuesto mayor ánimo. Salvar a mi país, mantener [ilegible] y abastecerlo de lo necesario para que ataque esa turba que [ilegible] es mi único, mi mayor anhelo. Afortunadamente [ilegible].

[Incompleta]

6

VALENTÍN GÓMEZ FARÍAS INFORMA SOBRE

\section{LA APROBACION DEL DECRETO*}

Excelentísimo señor general don

Antonio López de Santa Anna (s.f.).

No había contestado a usted por no desalentarlo exponiéndole las dificultades que pulsaba para mandarle auxilios; penetrado profundamente de la necesidad y de la obligación de mantener como es justo el ejército y de proveerlo de todo lo necesario para la campaña, pedí al Congreso que me autorizase para proporcionarme hasta 15000000 de pesos vendiendo o hipotecando bienes de manos muertas. La resistencia para hacerme esta concesión ha sido vigorosa y prolongada y la causa principal de ella ha provenido [ilegible] de los recelos que han debido inspirar varios hechos pasados a vista de todos. La memoria reciente de lo que hizo Haro, la conducta de Villamil, el recuerdo del ministerio de Trigueros, el temor de que se repitiesen los despilfarros y los contratos ruinosos de que se habló frecuentemente censurando a sus autores, ofrecían obstáculos que parecían insuperables para que se me diese la autorización que pretendía. Es verdad que a mí y a mis ministros nos han tratado los señores diputados con honor en todo el curso de la discusión, diciendo en ella públicamente que les inspirábamos confianza, pero sin embargo vacilaban y demostraban indecisos entre la esperanza y el temor, hasta que anoche han votado por fin la autorización como yo la quería: vamos pues, mi querido amigo, a tener muy pronto recursos su- 


\title{
SECUENCIA
}

ficientes con qué hacer la guerra, esa guerra santa necesaria y de honor en la que yo y todos los buenos mexicanos esperamos ver brillar el patriotismo, el valor y todas las virtudes militares.

Diré a usted para su satisfacción que en las galerías han aplaudido mucho los discursos de los señores ministros Ramírez y Zubieta, y que el pueblo y la clase media han dado en lo general señales públicas de adhesión a las opiniones del gobierno; no hay pues que temer por la ocupación de los bienes de manos muertas; el decreto se llevará a efecto sin conmoción, mas si por desgracia hubiere personas que la resistan abiertamente, las reprimiré con severidad. La uniformidad de la opinión de usted y la mía en esta materia, comprobada por la carta escrita al amigo Rejón, es un freno que contendrá a los que deseen turbar el orden.

0

Pásela usted muy bien mi apreciable amigo, y mande a su afectísimo amigo y servidor que atento besa su mano.

V.G.F. (rúbrica)

7

\section{VALENTÍN GÓMEZ FARÍAS INFORMA A SANTA ANNA DE LOS RECURSOS ENVIADOS*}

\begin{abstract}
A Antonio López de Santa Anna (s.1.), [fines de enero de 1847].
\end{abstract}

Son tantas las comunicaciones que vuestra excelencia se ha servido dirigir sobre las escaseces de recursos que padece ese ejército; tantas las veces que inculpa a la administración presente porque no le envía todo lo necesario como estableciendo acoso sin intención, comparación con la que le precedió haciendo resultar desventajosamente colocada la actual; y ha llegado a tanto el afán de vuestra excelencia en solicitud del envío de recursos que para encarecer su situación asegura no haber recibido un real en el presente mes. Empeño tan decidido no ha podido menos de fijar mi atención porque preveo el punto a que se pudiera conducir al gobierno supremo; y como el afrontar la cuestión por medio de comunicaciones oficiales sería embarazoso para vuestra excelencia y para mí, me he decidido a adoptar el confidencial y amistoso que me permite la libertad del idioma de la franqueza y verdad, que 


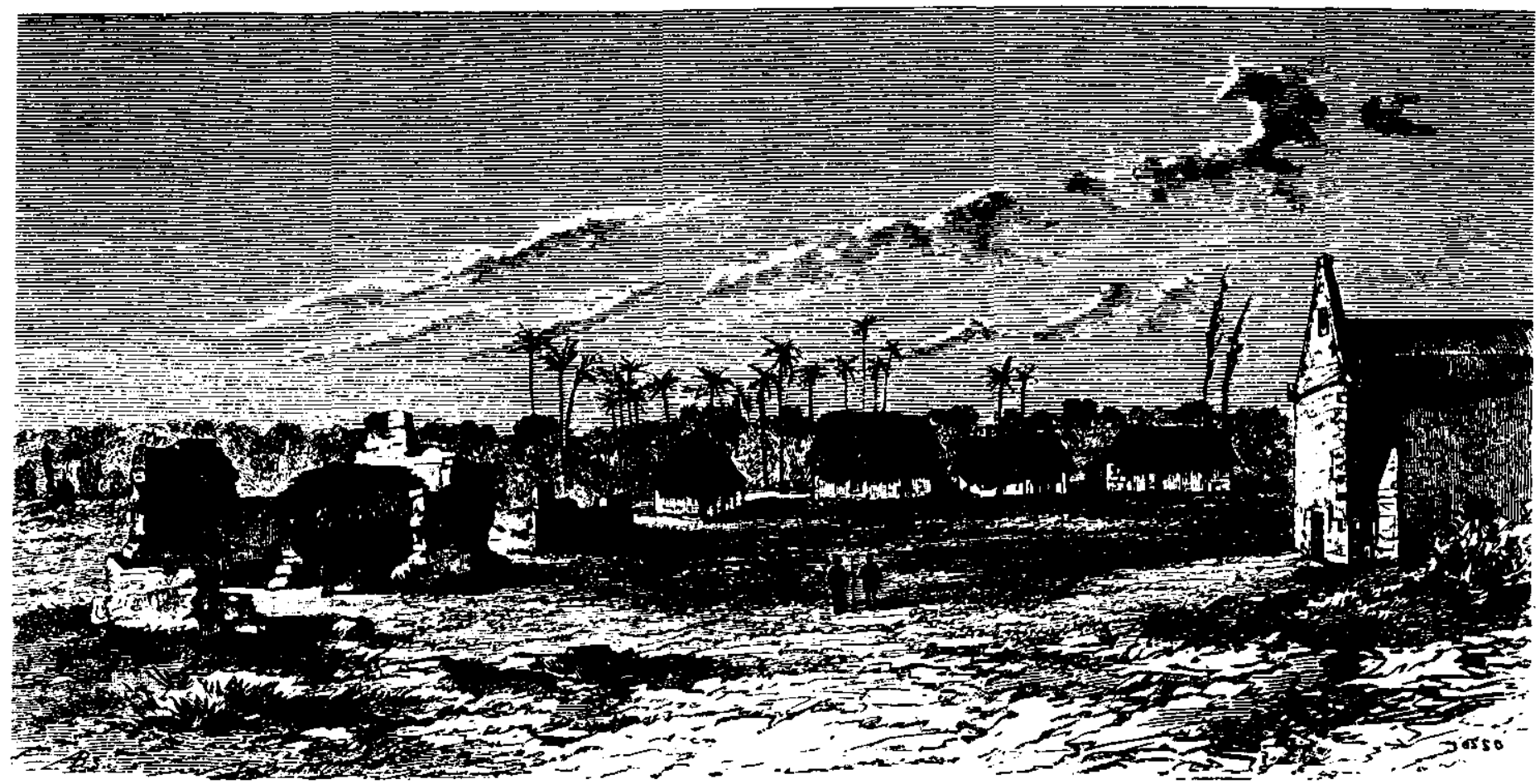

deben ser el distintivo de las relaciones entre funcionarios de la categoría en que nos ha colocado el voto de nuestros conciudadanos.

Debo confesar a vuestra excelencia que nada me sorprende tanto como la aseveración que se sirve hacer de que en el presente mes nada se le ha ministrado. Por los datos que tengo a la vista consta que ese estado ha auxiliado a vuestra excelencia con 11000 pesos de cuyas resultas he tenido que hacerme cargo del pago de las dietas de sus señores diputados: que el [ilegible] Zacatecas ha acudido a vuestra excelencia con 20000 pesos; el de Guanajuato con 17400 y pico de pesos; que se adjudicaron en su totalidad los derechos de la conducta de Tampico; que tengo dadas las órdenes necesarias para que se pongan a disposición de vuestra excelencia los productos de la venta o hipoteca de los bienes de manos muertas de los estados de San Luis, Guanajuato y Zacatecas, y previniendo aun el caso de que no puedan venderse o hipotecarse, he ordenado que los productos de los arrendamientos de fincas en esos estados y el de los réditos de capitales impuestos, se recauden y entren en la comisaría del ejército y todo esto sin contar con los auxilios que constantemente le franquea la venta del tabaco y que en cada mes no bajan de [en blanco en el original]. Con que si todo esto es cierto como lo acreditan los documentos que existen en el respectivo Ministerio ¿Cómo puede decirse que nada ha recibido vuestra excelencia? Mas si con esta aserción ha querido vuestra excelencia dar a entender que no ha llegado a percibir todo el haber que vence ese ejército, en este caso diré que tiene sobrada razón; pero también aseguraré al mismo tiempo que la administración actual no tiene culpa alguna en que la próxima anterior hubiera despilfa- 


\section{SECUENCIA}

rrado el tesoro público, ni le ha sido dado en el pequeño espacio de dos meses crear un erario que acuda a las más urgentes necesidades.

Cuando asiento que la administración anterior despilfarrólos caudales no quiero ser creído sobre mi palabra: hablaron los hechos. Pendiente la cuestión sobre ajuste de derechos de varios cargamentos por el arancel vigente o el que regía entonces y en cuya decisión se versaban de 400 a 500000 pesos se resolvió el negocio por medio de un contrato en que se introdujo una enorme suma de papeles nulificando así el ingreso al erario. Se solicitó también en su tiempo un permiso para exportación de platas pastas cuyos derechos ascendían a 105000 pesos; pues bien, en vez de percibir toda esa suma se contrató recibir sólo en numerario el pico de 5000 pesos y los 100000 en créditos en que se incluyó una escritura por valor de 30000 pesos cuyo paradero se ignora. Semejantes datos son suficientes para testificar mi aserción y me relevan de aglomerar [ilegible] con que me haría difuso.

No obstante la penosa situación en que encontré la hacienda nacional a mi ingreso al mando he cuidado con el mayor empeño de dejar a disposición de vuestra excelencia cuantos recursos han estado a mi alcance como fueron entre otros los 30000 pesos que en el mes anterior exhibió la mitra de Guadalajara; y no descanso un momento en hacer efectiva la ley de ocupación de bienes eclesiásticos para proporcionarle con sus resultados los auxilios que demanda ese ejército.

La conducta que observa en Sinaloa el comandante general don Ventura Mora es también otro obstáculo con que tropieza el gobierno en el ramo de hacienda. Él ha destituido a los empleados que le ha parecido conveniente y nombrado otros, sin estar en manera alguna autorizado para proceder de ese modo; y cuando se le ha prevenido los reponga y se ciña al cumplimiento de sus deberes, ha desobedecido al gobierno dejando burladas sus órdenes. Pero si este comportamiento es escandaloso, lo es aún más su procedimiento con las rentas públicas.

Hace pocos días que llegaron a Mázatlán dos buques con valioso cargamento que debió producir una suma respetable por derechos; pero el señor Mora deseoso de proporcionarse fondos, hizo arreglo con los interesados que disminuyeron mucho el producto, y realizado éste, se aplicó para sí 14000 pesos por sueldos atrasados, dejando al erario la mezquina suma de poco más de 20000 pesos por sus atenciones. Tan irregular conducta se le ha reprendido, pero me temo que sea sin fruto alguno, porque se ha querido... [incompleta]

V.G.F. 